\title{
Application of Health Belief Model on Child's Dental Visit Postponement during the COVID-19 Pandemic
}

\author{
Arlette Suzy Setiawan ${ }^{1, \odot \quad \text { Cucu Zubaedah }}$
}

\begin{abstract}
Address for correspondence Arlette Suzy Setiawan, drg., Sp.KGA(K), M.Si, Department of Paediatric Dentistry, Faculty of Dentistry, Universitas Padjadjaran, Jl. Sekeloa Selatan 1, Bandung, Indonesia (e-mail: arlette.puspa@fkg.unpad.ac.id).
\end{abstract}

Abstract

Keywords
- health belief model
- dental visit
postponement
- COVID-19
- pandemic

\section{Introduction}

Official data on the number of children affected by coronavirus disease 2019 (COVID-19) in Indonesia are yet to be released, but several national newspapers have reported the existence of pediatric patients with COVID-19 like symptoms. Pediatric cases of COVID-19 infection are typically mild, but underlying coinfection may be more common in children than in adults, according to an analysis of clinical, laboratory, and chest computed tomographic features of pediatric inpatients in Wuhan, China. ${ }^{1}$ Although symptoms in children are often mild or even without symptoms, it does not mean there are no children at risk of more serious illness. Children are susceptible to severe acute respiratory syndrome coronavirus 2 (SARS-CoV-2) infection. ${ }^{2}$ The risk attributable to severe illness of COVID-19 in children is difficult to see. In addition, children also can play a major role in community-based virus transmission. ${ }^{3}$ In other words, children could be facilitators of viral transmission. ${ }^{2}$ This transmission occurs more easily in places where many children meet, namely playgrounds, schools, and child care centres. ${ }^{3}$ Therefore, during this pandemic study from home is applied by the government.

As any other respiratory viruses, SARS-CoV-2 is also transmitted via droplets that are generated by coughing or sneezing. It is less widely known that normal speaking also produces thousands of oral fluids droplets. Recently, speech droplets generated by asymptomatic carriers of SARS-CoV-2 are increasingly considered to be a likely mode of disease transmission. ${ }^{4}$ In addition, according to a latest report on COVID-19, the virus is detectable in saliva, which had drawn attention to a risk catching the disease in an environment that includes a large number of saliva, such as dental treatment. ${ }^{5}$

As COVID-19 is mainly spread through droplets and contacts, potential airborne dissemination has been ruled out except for surroundings where aerosol generation is of concern, including but not limited to endotracheal intubation, bronchoscopy, and the patient being disconnected from a ventilator. ${ }^{6}$ Considering the high risk of transmission of 
COVID-19 in dental setting, as the development of confirmed cases has increased, several dental care facilities in Indonesia and many other affected countries have been completely closed or have been only providing minimal treatment for emergency cases. ${ }^{7}$ In addition to emergency cases, other dental visits are recommended to be postponed to break the chain of COVID-19 transmission. Along with this recommendation, communities were recommended to maintain healthy behavior during the pandemic. However, this context must be accompanied by a community understanding of other health behavior, such as oral health behavior along with other factors in preventing the COVID-19 exposure itself.

Promoting health behaviors is key in preventing a disease ${ }^{8}$; in this case dental disease plays a role in delaying dental visits to prevent COVID-19 exposure. Therefore, it is very necessary to promote healthy behavior through behavior change models. ${ }^{9}$ One important model that has been proven to predict health behavior is the health belief model (HBM), which was developed by Hochbaum and Rosenstock in the 1950s. ${ }^{10} \mathrm{HMB}$ initially has a perception of vulnerability, perceived severity, perceived obstacles, perceived benefits, and cues to act as constructs; self-efficacy is then added. According to HBM, when an individual sees themselves as vulnerable or at risk for certain health conditions (perception of susceptibility), he must be aware of the seriousness or consequences of the disease (perception of severity), believing in positive results when preventive action is taken (perceived benefits) and that the benefits are greater than the related obstacles (perceived barriers), there are also activities or events that motivate individual prevention behavior (cues of action) coupled with confidence to bring the desired behavior (self-efficacy), that is, belief in yourself to master the courage to execute the required behavior will greatly help the individual demonstrate the necessary behavioral changes. ${ }^{11}$ This study is aimed to analyze parental perception on child's dental visit postponement using HBM during the pandemic of COVID-19.

\section{Materials and Methods}

\section{Design and Sample}

Cross-sectional survey design was chosen as an appropriate design for this study that was performed between March, 2020 and May, 2020. A purposive sample was recruited online by distributing questionnaires through a clickable link among caregivers of patients registered at two pediatric dental clinics in Bandung. Only caregivers with children below 12 years of age were included in this study. The study was ethically approved by Universitas Padjadjaran Ethical Committee, to establish informed consent; all respondents received a detailed explanation of the study purpose and their rights to confidentiality. The structured questionnaires took 15 to 20 minutes to complete, which consisted 26 questions on sociodemographic data of respondents, including perceived susceptibility, perceived severity, perceived benefit, perceived barrier, cues to action, self-efficacy, and locus of control. Also, 5-point Likert scale was applied to value the responses to each item (1 strongly agree to 5 strongly disagree). Questions were not only about how to prevent COVID19 but also about how to prevent dental diseases that possibly may occur to postpone the dental visits in the first place. The questionnaires have been pretested online to a community within Antapani District in Bandung City, Indonesia. After processing the pretest result using Cronbach- $\alpha$, reliability co-efficient of 0.84 was obtained, making the instrument highly reliable.

\section{Data Analysis}

The data collected was cleaned, coded, and processed using Statistical Package for Social Science (SPSS) version 22.0 software. The result was represented in the form of frequencies, percentages, and means. The bivariate relationship was determined between the demographic characteristics of respondents and construct of the HBM.

\section{Result}

The objective of the study was to analyze how the construct of the HBM (perceived susceptibility, perceived severity, perceived benefit, perceived barrier, cues to action, self-efficacy, and locus of control) relates to postponing child's dental visit during the pandemic of COVID-19. Thus, the result from respondents on perceived susceptibility is presented in

\section{- Table 1.}

- Table 1 represents the analysis of the responses regarding respondents perceived susceptibility on child's dental visit postponement. Respondents who responded that children could be exposed to COVID-19 (37\%, $\bar{\chi}=2.84, \mathrm{SD}=1.20)$ were almost as high as those who gave responses that they didn't know (37.8\%, $\bar{\chi}=2.84, \mathrm{SD}=1.20)$. Meanwhile, the level of acceptance as to whether the respondent was worried that their children might be getting viral exposure from the dentist was high $(35.1 \%, \bar{\chi}=3.15$, standard deviation $[S D]=1.27$ ). The SD showed that the respondents' responses were clustered around the mean. The general mean of respondent perceived susceptibility of their children's risk exposed to the virus was determined to be indifferent (general mean $=3.07$ ). On perceived severity, the results in - Table 2 provided the participant thought about the negative consequences a child associates with getting exposed to virus.

As shown in - Table 2, most participants believe that their children will not be able to isolate themselves if they are exposed by the virus $(\bar{\chi}=3.32$ with $\mathrm{SD}=1.31)$. The SD indicates that the respondents were unanimous in their responds. As for the consequences such as a child can get seriously ill after being exposed to the virus, participants who respond agree and disagree are almost in the same proportion ( 40.5 vs. $38.8 \%$; $\chi=-2.98$, SD $=1.33$ ). Most participant responded that they don't know whether the virus may lower child's immune system (33.3\%) or appetite $33.3 \%)$. Thus, from the analysis, participant's perceived severity was 
Table 1 Perceived susceptibility

\begin{tabular}{|c|c|c|c|c|}
\hline Variable & Frequency & Percentage & $\bar{\chi}$ & SD \\
\hline \multicolumn{3}{|c|}{ Child's risk of exposure to the virus } & \multirow[t]{6}{*}{2.84} & \multirow[t]{6}{*}{1.20} \\
\hline Strongly agree & 18 & 16.3 & & \\
\hline Agree & 23 & 20.7 & & \\
\hline Don’t know & 42 & 37.8 & & \\
\hline Disagree & 15 & 13.5 & & \\
\hline Strongly disagree & 13 & 11.7 & & \\
\hline \multicolumn{3}{|c|}{ Viral exposure from clinic environment } & \multirow[t]{6}{*}{3.25} & \multirow[t]{6}{*}{1.30} \\
\hline Strongly agree & 16 & 14.4 & & \\
\hline Agree & 14 & 12.6 & & \\
\hline Don’t know & 27 & 24.3 & & \\
\hline Disagree & 34 & 30.6 & & \\
\hline Strongly disagree & 20 & 18.1 & & \\
\hline \multicolumn{3}{|c|}{ Viral exposure from other patients } & \multirow[t]{6}{*}{3.03} & \multirow[t]{6}{*}{1.35} \\
\hline Strongly agree & 19 & 17.1 & & \\
\hline Agree & 23 & 20.7 & & \\
\hline Don’t know & 22 & 19.8 & & \\
\hline Disagree & 29 & 26.1 & & \\
\hline Strongly disagree & 18 & 16.3 & & \\
\hline \multicolumn{3}{|c|}{ Viral exposure from the dentist } & \multirow[t]{6}{*}{3.15} & \multirow[t]{6}{*}{1.27} \\
\hline Strongly agree & 11 & 9.9 & & \\
\hline Agree & 28 & 25.2 & & \\
\hline Don’t know & 26 & 23.4 & & \\
\hline Disagree & 25 & 22.5 & & \\
\hline Strongly disagree & 21 & 19 & & \\
\hline
\end{tabular}

Abbreviation: SD, standard deviation.

$\bar{\chi}=$ mean.

indifferent $(\chi=2.99)$. This is an indication that the majority of respondents perceived that they don't know the severity of the virus, and could give their child in to treatment.

On perceived benefits, the results in - Table 3 provide what the respondents thought about the benefit of postponing their child's dental visit during the pandemic to prevent SARS-CoV-2 exposure. Most respondents believed that postponing their child's dental visit was likely to develop a healthy behavior $(\bar{\chi}=2.16, \mathrm{SD}=0.75)$ along with hand hygiene habit $(\bar{\chi}=2.14, S D=0.77)$. In relation to respondents believing that postponing child's dental visit was not likely to limit their children from sweet snacking, the values were $\bar{\chi}=3.27, \mathrm{SD}=1.16$. The general mean of perceived benefit was $\bar{\chi}=2.54$, an indication that the majority of respondents perceived there were benefits for postponing dental visit.

- Table 4 depicts the analysis of the responses regarding perceived barriers to postpone child's dental visit. The respondents did not agree that their health beliefs $(\bar{\chi}=3.80$, $\mathrm{SD}=0.97$ ) would not be a barrier for them to postponing the dental visits. Similarly, their inability to overcome a child's dental pain $(\bar{\chi}=3.87, \mathrm{SD}=0.97)$ would not be a barrier in a child's dental visit postponement. But, in relation to the
Table 2 Perceived severity

\begin{tabular}{|c|c|c|c|c|}
\hline Variable & Frequency & Percentage & $\bar{\chi}$ & SD \\
\hline \multicolumn{3}{|c|}{ Having the child to self-isolate } & \multirow[t]{6}{*}{3.32} & \multirow[t]{6}{*}{1.31} \\
\hline Strongly agree & 16 & 14.4 & & \\
\hline Agree & 16 & 14.4 & & \\
\hline Don’t know & 14 & 12.6 & & \\
\hline Disagree & 46 & 41.4 & & \\
\hline Strongly disagree & 19 & 17.2 & & \\
\hline \multicolumn{3}{|c|}{ Declining immune system } & \multirow[t]{6}{*}{2.80} & \multirow[t]{6}{*}{1.18} \\
\hline Strongly agree & 20 & 18.0 & & \\
\hline Agree & 22 & 19.8 & & \\
\hline Don't know & 37 & 33.3 & & \\
\hline Disagree & 24 & 21.6 & & \\
\hline Strongly disagree & 8 & 7.2 & & \\
\hline \multicolumn{3}{|l|}{ Getting seriously ill } & \multirow[t]{6}{*}{2.98} & \multirow[t]{6}{*}{1.33} \\
\hline Strongly agree & 18 & 16.2 & & \\
\hline Agree & 27 & 24.3 & & \\
\hline Don’t know & 23 & 20.7 & & \\
\hline Disagree & 25 & 22.5 & & \\
\hline Strongly disagree & 18 & 16.3 & & \\
\hline \multicolumn{3}{|c|}{ Decreasing appetite } & \multirow[t]{6}{*}{2.88} & \multirow[t]{6}{*}{1.18} \\
\hline Strongly agree & 16 & 14.4 & & \\
\hline Agree & 25 & 22.5 & & \\
\hline Don't know & 37 & 33.3 & & \\
\hline Disagree & 22 & 19.8 & & \\
\hline Strongly disagree & 11 & 10.0 & & \\
\hline
\end{tabular}

Abbreviation: SD, standard deviation.

$\bar{\chi}=$ mean.

pre-existing child's dentāl disease, the most respondents $(\bar{\chi}=2.62, \mathrm{SD}=0.74)$ responded that it would hinder the child's dental visit postponement. Generally, the mean of the respondents' perceived barriers was confirmed $(\bar{\chi}=3.38)$. This indicates that the majority of respondents perceived that there were no barriers in postponing child's dental visit during this pandemic. Another area considered in HBM was cues to action to postpone child's dental visit as indicated in - Table 5.

The results in - Table 5 show that most respondents agreed $(\bar{\chi}=2.06, \mathrm{SD}=0.91)$ that they can do a domestic treatment (first aid measures) to overcome child's dental pain before consulting the dental office. Similarly, online consultation with the dentist $(\bar{\chi}=2.06, \mathrm{SD}=0.91$ ) will be the action that they would take if their child experiences dental pain during this pandemic. Over all, the general mean $(\bar{\chi}=2.05)$ indicates that the awareness of respondents in the efforts in postponing child's dental visit was good.

Results in - Table 6 show that most respondents (56.76\%) will postpone their child's dental visit. This result also applies to respondents who thought about what they will do, such as consulting online about their child's 
Table 3 Perceived benefit

\begin{tabular}{|c|c|c|c|c|}
\hline Variable & Frequency & Percentage & $\bar{\chi}$ & SD \\
\hline \multicolumn{3}{|c|}{ Developing healthy behavior } & \multirow[t]{6}{*}{2.16} & \multirow[t]{6}{*}{0.75} \\
\hline Strongly agree & 23 & 20.72 & & \\
\hline Agree & 47 & 42.34 & & \\
\hline Don't know & 41 & 36.94 & & \\
\hline Disagree & 0 & 0 & & \\
\hline Strongly disagree & 0 & 0 & & \\
\hline \multicolumn{3}{|c|}{ Developing hand sanitary habit } & \multirow[t]{6}{*}{2.14} & \multirow[t]{6}{*}{0.77} \\
\hline Strongly agree & 25 & 22.52 & & \\
\hline Agree & 46 & 41.44 & & \\
\hline Don't know & 39 & 35.13 & & \\
\hline Disagree & 1 & 0.01 & & \\
\hline Strongly disagree & 0 & 0 & & \\
\hline \multicolumn{3}{|c|}{ Habituating tooth brushing } & \multirow[t]{6}{*}{2.59} & \multirow[t]{6}{*}{1.01} \\
\hline Strongly agree & 16 & 14.41 & & \\
\hline Agree & 36 & 32.43 & & \\
\hline Don't know & 42 & 37.84 & & \\
\hline Disagree & 12 & 10.81 & & \\
\hline Strongly disagree & 5 & 4.51 & & \\
\hline \multicolumn{3}{|c|}{ Limiting sweet snacking } & \multirow[t]{6}{*}{3.27} & \multirow[t]{6}{*}{1.16} \\
\hline Strongly agree & 8 & 7.21 & & \\
\hline Agree & 18 & 16.22 & & \\
\hline Don't know & 42 & 37.84 & & \\
\hline Disagree & 22 & 19.82 & & \\
\hline Strongly disagree & 21 & 18.91 & & \\
\hline
\end{tabular}

Abbreviation: SD, standard deviation.

$\bar{\chi}=$ mean.

Table 4 Perceived barriers

\begin{tabular}{|c|c|c|c|c|}
\hline Variable & Frequency & Percentage & $\bar{\chi}$ & SD \\
\hline \multicolumn{3}{|c|}{ Pre-existing dental disease } & \multirow[t]{6}{*}{2.62} & \multirow[t]{6}{*}{0.74} \\
\hline Strongly agree & 8 & 7.21 & & \\
\hline Agree & 35 & 31.53 & & \\
\hline Don't know & $59-$ & 53.15 & & \\
\hline Disagree & 9 & 8.11 & & \\
\hline Strongly disagree & 0 & 0 & & \\
\hline \multicolumn{3}{|c|}{ Unable to overcome child's dental pain } & \multirow[t]{6}{*}{3.72} & \multirow[t]{6}{*}{1.02} \\
\hline Strongly agree & 4 & 3.60 & & \\
\hline Agree & 11 & 9.91 & & \\
\hline Don’t know & 20 & 18.02 & & \\
\hline Disagree & 53 & 47.75 & & \\
\hline Strongly disagree & 23 & 20.73 & & \\
\hline \multicolumn{3}{|c|}{ Health belief hindering the postpone } & \multirow[t]{6}{*}{3.80} & \multirow[t]{6}{*}{0.97} \\
\hline Strongly agree & 4 & 3.60 & & \\
\hline Agree & 3 & 2.70 & & \\
\hline Don’t know & 32 & 28.83 & & \\
\hline Disagree & 44 & 39.64 & & \\
\hline Strongly disagree & 28 & 25.23 & & \\
\hline
\end{tabular}

Abbreviation: SD, standard deviation.

$\bar{\chi}=$ mean.
Table 5 Cues to action

\begin{tabular}{|c|c|c|c|c|}
\hline Variable & Frequency & Percentage & $\bar{\chi}$ & SD \\
\hline \multicolumn{3}{|c|}{ Domestic treatment of child's dental pain } & \multirow[t]{6}{*}{2.06} & \multirow[t]{6}{*}{0.91} \\
\hline Strongly agree & 38 & 34.23 & & \\
\hline Agree & 33 & 29.73 & & \\
\hline Don’t know & 35 & 31.53 & & \\
\hline Disagree & 5 & 4.51 & & \\
\hline $\begin{array}{l}\text { Strongly } \\
\text { disagree }\end{array}$ & 0 & 0 & & \\
\hline \multicolumn{3}{|c|}{ Online consultation with the dentist } & \multirow[t]{6}{*}{2.05} & \multirow[t]{6}{*}{0.91} \\
\hline Strongly agree & 38 & 34.23 & & \\
\hline Agree & 35 & 31.53 & & \\
\hline Don’t know & 33 & 29.73 & & \\
\hline Disagree & 5 & 4.51 & & \\
\hline $\begin{array}{l}\text { Strongly } \\
\text { disagree }\end{array}$ & 0 & 0 & & \\
\hline \multicolumn{3}{|c|}{ Limit child's sweet snacks } & \multirow[t]{6}{*}{2.04} & \multirow[t]{6}{*}{0.91} \\
\hline Strongly agree & 39 & 35.13 & & \\
\hline Agree & 34 & 30.63 & & \\
\hline Don’t know & 33 & 29.73 & & \\
\hline Disagree & 5 & 4.51 & & \\
\hline $\begin{array}{l}\text { Strongly } \\
\text { disagree }\end{array}$ & 0 & 0 & & \\
\hline \multicolumn{3}{|c|}{ Guiding child in tooth brushing } & \multirow[t]{6}{*}{2.06} & \multirow[t]{6}{*}{0.93} \\
\hline Strongly agree & 39 & 35.13 & & \\
\hline Agree & 31 & 27.93 & & \\
\hline Don’t know & 36 & 32.43 & & \\
\hline Disagree & 5 & 4.51 & & \\
\hline $\begin{array}{l}\text { Strongly } \\
\text { disagree }\end{array}$ & 0 & 0 & & \\
\hline
\end{tabular}

Abbreviation: SD, standard deviation.

$\bar{\chi}=$ mean.

dental pain (67.57\%), training tooth brushing to their children (69.37\%), and limiting their sweet snacking (66.67\%). In general, the mean $\chi=2.08$ indicates that the respondents have their belief in their capacity to execute behaviors necessary to postpone child's dental visit during this pandemic.

The concept that refers to how strongly respondents believe they have control over the situations that affect their lives can be analyzed from the result in - Table 7 . Most of the respondents $(51 \%, \chi=3.31, \mathrm{SD}=1.30)$ disagreed that they were responsible for not being a role model to their children in toothbrushing habits. But, in relation to being responsible to child's dental pain, most respondents (36.94\%) thought indifferently, while in specific cases like not limiting their child's sweet snacking habits, most respondents highly (54.06\%) thought of themselves to be responsible. The general mean $(\chi=2.88)$ shows that locus of control for respondents was indifferent in postponing child's dental visit. Bivariate relationship between the demographic variables and the construct of the HBM is provided in - Table 8 . 
Table 6 Self-efficacy

\begin{tabular}{|c|c|c|c|c|}
\hline Variable & Frequency & Percentage & $\bar{\chi}$ & SD \\
\hline \multicolumn{3}{|c|}{ Postponing child's dental visit } & \multirow[t]{6}{*}{2.18} & \multirow[t]{6}{*}{0.92} \\
\hline Strongly agree & 33 & 29.73 & & \\
\hline Agree & 30 & 27.03 & & \\
\hline Don't know & 43 & 38.74 & & \\
\hline Disagree & 5 & 4.50 & & \\
\hline Strongly disagree & 0 & 0 & & \\
\hline \multicolumn{3}{|c|}{ Online consultation with the dentist } & \multirow[t]{6}{*}{2.03} & \multirow[t]{6}{*}{1.05} \\
\hline Strongly agree & 45 & 40.54 & & \\
\hline Agree & 30 & 27.03 & & \\
\hline Don't know & 26 & 23.42 & & \\
\hline Disagree & 8 & 7.21 & & \\
\hline Strongly disagree & 2 & 1.80 & & \\
\hline \multicolumn{3}{|c|}{ Modeling tooth brushing } & \multirow[t]{6}{*}{2.05} & \multirow[t]{6}{*}{1.02} \\
\hline Strongly agree & 41 & 36.94 & & \\
\hline Agree & 36 & 32.43 & & \\
\hline Don't know & 24 & 21.62 & & \\
\hline Disagree & 8 & 7.21 & & \\
\hline Strongly disagree & 2 & 1.80 & & \\
\hline \multicolumn{3}{|c|}{ Limit child's sweet snacks } & \multirow[t]{6}{*}{2.05} & \multirow[t]{6}{*}{1.03} \\
\hline Strongly agree & 42 & 37.84 & & \\
\hline Agree & 32 & 28.83 & & \\
\hline Don't know & 28 & 25.23 & & \\
\hline Disagree & 7 & 6.30 & & \\
\hline Strongly disagree & 2 & 1.80 & & \\
\hline
\end{tabular}

Abbreviation: SD, standard deviation.

$\bar{\chi}=$ mean.

The analysis of - Table 8 reveals that there were only two strong and nine moderate correlated relationships. First, self-efficacy strongly correlated with cue of action. As expected, an increase in individual's self-efficacy is likely to trigger an action to postpone child's dental visit. Second, locus of control strongly correlated with perceived severity. Individuals having negative control over a situation that may lead to a situation are likely to have low perceptions of what the consequences would be following their actions.

\section{Discussion}

The objective of the study was to determine how some of the construct of HBM relate to caregiver's postponing their child's dental visit during the pandemic of COVID-19. The conceptual framework is guided by the HBM. This type of psychological model used in predicting whether a person will carry out an activity that is needed to prevent an illness or not, depends on the person's beliefs or perceptions about the seriousness of the disease, the advantages and disadvantages of prevention activities, and one's own ability to carry out activities. The perceived susceptibility of a person to a
Table 7 Locus of control

\begin{tabular}{|c|c|c|c|c|}
\hline Variable & Frequency & Percentage & $\bar{\chi}$ & SD \\
\hline \multicolumn{3}{|c|}{ Not a role model for tooth brushing } & \multirow[t]{6}{*}{3.31} & \multirow[t]{6}{*}{1.30} \\
\hline Strongly agree & 15 & 13.51 & & \\
\hline Agree & 14 & 12.61 & & \\
\hline Don’t know & 25 & 22.52 & & \\
\hline Disagree & 35 & 31.53 & & \\
\hline Strongly disagree & 22 & 19.82 & & \\
\hline \multicolumn{3}{|c|}{ Responsible for child's dental pain } & \multirow[t]{6}{*}{3.06} & \multirow[t]{6}{*}{1.24} \\
\hline Strongly agree & 14 & 12.61 & & \\
\hline Agree & 20 & 18.02 & & \\
\hline Don't know & 41 & 36.94 & & \\
\hline Disagree & 17 & 15.32 & & \\
\hline Strongly disagree & 19 & 17.12 & & \\
\hline \multicolumn{3}{|c|}{ Did not limit sweet snacking } & \multirow[t]{6}{*}{2.26} & \multirow[t]{6}{*}{0.90} \\
\hline Strongly agree & 28 & 25.23 & & \\
\hline Agree & 32 & 28.83 & & \\
\hline Don’t know & 45 & 40.54 & & \\
\hline Disagree & 6 & 5.40 & & \\
\hline Strongly disagree & 0 & 0 & & \\
\hline
\end{tabular}

Abbreviation: SD, standard deviation.

$\bar{\chi}=$ mean.

disease, the perception of the severity of the disease, the perceived benefits of preventive action, perceived barriers to preventive action, certain cues for taking preventive actions, and one's self-efficacy all interact within a person to determine that person's readiness to take preventative measures. ${ }^{12}$

Results from the study show that respondents' perceived susceptibility of their children's risk of getting exposed to the virus was that of being indifferent. Human beings, in general, need some form of motivation to change a particular behavioral pattern. ${ }^{11}$ The study discovered that the respondents perceived their children susceptibility of getting exposed to COVID-19 in a dental setting as indifferent. This might be due to a lack of knowledge about COVID-19 in children. ${ }^{3}$ In other words, most mild cases of COVID-19 in children affected respondents' perception of their child's susceptibility. This result also applies to respondents' perception of severity.

In terms of other constructs of the model, as the study revealed, perceived benefit, cue of action, and self-efficacy were confirmed in postponing child's dental visit. Perceived benefits are another construct of HBM that refers to one's beliefs about the benefit of recommended behaviors in reducing the risk of a diseases or its consequences. ${ }^{13}$ In the present study, respondents perceived that there were benefits that they will get after performing an action. In this study, respondents described their thought about the benefit of taking preventive measure of postponing their children's dental visit during the pandemic, including developing positive healthy behavior that will be useful for everyday life after the pandemic. Perceived benefit is formed based on individual's opinions about the used value of a new behavior in reducing 
Table 8 Bivariate relationship between the demographic variables and the construct of the HBM

\begin{tabular}{|c|c|c|c|c|c|c|c|c|c|c|}
\hline Correlation & Age & Sex & Education & $\begin{array}{l}\text { Perceived } \\
\text { susceptibility }\end{array}$ & $\begin{array}{l}\text { Perceived } \\
\text { severity }\end{array}$ & $\begin{array}{l}\text { Perceived } \\
\text { benefit }\end{array}$ & $\begin{array}{l}\text { Perceived } \\
\text { barriers }\end{array}$ & $\begin{array}{l}\text { Cues to } \\
\text { action }\end{array}$ & $\begin{array}{l}\text { Self- } \\
\text { efficacy }\end{array}$ & $\begin{array}{l}\text { Locus of } \\
\text { control }\end{array}$ \\
\hline Age & 1 & & & & & & & & & \\
\hline Sex & -0.075 & 1 & & & & & & & & \\
\hline Education & -0.106 & -2.95 & 1 & & & & & & & \\
\hline $\begin{array}{l}\text { Perceived } \\
\text { susceptibility }\end{array}$ & 0.027 & 0.050 & 0.108 & 1 & & & & & & \\
\hline $\begin{array}{l}\text { Perceived } \\
\text { severity }\end{array}$ & \begin{tabular}{|l|}
0.062 \\
\end{tabular} & -0.056 & 0.059 & 0.745 & 1 & & & & & \\
\hline $\begin{array}{l}\text { Perceived } \\
\text { benefit }\end{array}$ & -0.025 & v0.169 & -0.056 & 0.009 & -0.007 & 1 & & & & \\
\hline $\begin{array}{l}\text { Perceived } \\
\text { barriers }\end{array}$ & -0.222 & -0.075 & 0.195 & -0.087 & 0.014 & -0.258 & 1 & & & \\
\hline $\begin{array}{l}\text { Cues to } \\
\text { action }\end{array}$ & -0.215 & -0.198 & 0.270 & 0.305 & 0.271 & 0.344 & -0.245 & 1 & & \\
\hline Self-efficacy & 0.366 & -0.209 & 0.093 & 0.104 & 0.108 & 0.382 & -0.499 & $0.694^{*}$ & 1 & \\
\hline $\begin{array}{l}\text { Locus of } \\
\text { control }\end{array}$ & 0.441 & -0.158 & 0.159 & 0.489 & $0.508^{*}$ & 0.095 & 0.057 & 0.362 & 0.372 & 1 \\
\hline
\end{tabular}

Abbreviation: HBM, health belief model.

*significance alpha 5\%

the risk of developing a disease. Communities tend to adopt healthier behaviors when there is a belief in themselves that the behavior of adoption will reduce the chance of developing more severe illness in them. ${ }^{14}$ Based on the HBM, the guidance that people receive from their surroundings (cues to actions) is effective in developing their behavior. ${ }^{15}$ Cue of action in this study was domestic treatment of child's dental pain, online consultation with the dentist, limiting child's sweet snack, and guiding child in tooth brushing. These were all actions that were easy to be conquered by caregivers.

Health-related behaviors are also a function of perceived barriers to taking action. Perceived barriers refer to an individual's assessment of the obstacles to behavior change. Even if an individual perceives a health condition as threatening and believes that a particular action will effectively reduce the threat, barriers may prevent engagement in the health-promoting behavior. In other words, the perceived benefits must outweigh the perceived barriers in order for behavior change to occur. ${ }^{16}$ In this study the aspect that may hinder the child's dental visit postponement is the pre-existing dental disease. Most parents are not aware of their child's dental disease until the child has a complaint. ${ }^{17}$

\section{Conclusion}

This study provided evidence that HBM is applicable to children's dental visit postponement during the pandemic of COVID-19. By knowing parents' health beliefs, a counselling plan can then be made related to the postponement in visiting the dentist during this pandemic. Moreover, policy makers should increase the accessibility of dental resources to enhance the utilization of dental care and dental education during this period. The limitation of this study is the lack of male respondents, so the results cannot analyze differences in male and female health beliefs. The form of response bias from respondents may also limit the study. The point is that the information provided by respondents through a questionnaire sometimes doesn't show the actual opinion of the respondents. This can happen because of the inability of respondents to understand the contents of questions and dishonesty of respondents in answering the questions or when filling out the questionnaire incorrectly.

\section{Conflict of Interest}

None declared.

\section{Reference}

1 Xia W, Shao J, Guo Y, Peng X, Li Z, Hu D. Clinical and CT features in pediatric patients with COVID-19 infection: different points from adults. Pediatr Pulmonol 2020; 55(5):1169-1174

2 Kelvin AA, Halperin S. COVID-19 in children: the link in the transmission chain. Lancet Infect Dis 2020; 20(6):633-634

3 Cruz AT, Zeichner SL. COVID-19 in children: initial characterization of the pediatric disease. Pediatrics 2020; 145(6):1-3

4 Stadnytskyi V, Bax CE, Bax A, Anfinrud P. The airborne lifetime of small speech droplets and their potential importance in SARS-CoV-2 transmission. Proc Natl Acad Sci USA 2020; 117(22):11875-11877

5 Xu J, Li Y, Gan F, Du Y, Yao Y. Salivary glands: potential reservoirs for COVID-19 asymptomatic infection. J Dent Res 2020; (April):22034520918518

6 Hamid H, Khurshid Z, Adanir N, Zafar MS, Zohaib S. COVID19 pandemic and role of human saliva as a testing biofluid in point-of-care technology 2020. Eur J Dent:2020;14(suppl S1):S123-S129 doi:10.1055/s-0040-1713020

7 Alharbi A,Alharbi S,Alqaidi S. Guidelines for dental care provision during the COVID-19 pandemic. Saudi Dent J 2020; 32:181-186

8 Martino S. Oral health behavioral and social intervention research concepts and methods. J Public Health Dent 2011; 71(1, Suppl 1):S2-S6 
9 Moodi M, Mood MB, Sharifirad GR, Shahnazi H, Sharifzadeh G. Evaluation of breast self-examination program using Health Belief Model in female students. J Res Med Sci 2011; 16(3):316-322

10 Setiawan AS, Kendhawati L, Agustiani H. Relational model between parental dental belief and formation of dental fear among preschool children in Indonesia. Eur J Dent 2019; 13(3):426-431

11 Nyeseh Ofori K. Application of the health belief model to HIV testing and counselling among youth living in selected rural communities in Ghana. Int J HIV/AIDS Prev Educ. Behav Sci (Basel) 2019; 5 (1):11-18

12 Chen MF, Wang RH, Schneider JK, et al. Using the Health Belief Model to understand caregiver factors influencing childhood influenza vaccinations. J Community Health Nurs 2011; 28(1):29-40
13 Sharma M, Romas JA. Theoretical Foundations of Health Education and Health Promotion. 3rd edition. Ontario: Jones \& Bartlett Learning; 2016:294

14 Attamimy HB, Qomaruddin MB. AAplication of Health Belief Model on behavior to prevent Dengue fever. J Promkes 2017; 5(2):245-255

15 Glanz K, Rimer BK, Viswanath K. Health Behavior, Theory, Research and Practice. 5th edition. San Francisco, CA: John Wiley \& Sons; 2015:512

16 Reed M, Llyod B. Health Psychology. 1st edition. Waltham Abbey Essex: ED-Tech Press; 2018:325

17 Putri Abadi NYW, Suparno S. Parents perpective on childrens oral health. J Obs J Pendidik Anak Usia Dini 2019; 3(1):161-169 